\title{
Pre-service Primary Teachers' Teaching Styles and Attitudes towards the Use of Technology in Mathematics Classrooms
}

\author{
José M. Marbán ${ }^{1 *}$, Eddie M. Mulenga ${ }^{2}$ \\ ${ }^{1}$ University of Valladolid, SPAIN \\ ${ }^{2}$ The Copperbelt University, ZAMBIA \\ *CORRESPONDENCE: \josemaria.marban@uva.es
}

\begin{abstract}
The integration of ICT in formal teaching and learning environments has become more and more relevant along the last decades. However, its use in the mathematics classroom seems to be still far from initial expectations. This paper shows the results from a research conducted to get some insight about such a gap by analyzing the relationship between pre-service primary teachers' teaching styles in teaching and learning mathematics and their attitudes towards the use of technology in mathematics classrooms. Analysis of Variances and step-wise multiple regression analysis were performed over the data provided by one hundred and sixty three participants by completing survey questionnaires. The results indicate that pre-service teachers' year of study has no significant impact on the integration of ICT in the teaching and learning of mathematics while teaching styles and gender do have. Furthermore, age, gender and teaching styles are capable predictors for the construction of the regression model and it is deduced that teaching styles have a predictive ability on the integration of ICT in mathematics classrooms.
\end{abstract}

Keywords: attitudes, ICT, mathematics, pre-service teachers, teaching styles

\section{INTRODUCTION}

For many years educators have been exploring different strategies and approaches to improve the quality of education and to improve overall learning processes. Although many facets have been analyzed in the context of mathematics education such as student achievement, parental involvement, learning conditions, teacher training, school curriculum and standardized testing, among others, it seems that more attention is still required by some other factors such as the affective domain in mathematics, the integration of information and communication technology (ICT) in the mathematics classroom and the combined dynamics of learning and teaching styles.

The education sector in Spain has been undergoing several reforms and mathematics education has not been left out. In particular, the most recent policy proposals have included as a key point the inclusiveness of ICTs in mathematics attending thus meeting a demand characteristic of our current digital era. It is important to realize that in these new technological coordinates teachers do still matter, but what is ironic, is that there is no consensus about a reliable or objective way of identifying excellent teachers. Thus, although teachers are categorized as novice, experienced and experts in their profession, what makes a teacher good, an expert or an excellent teacher is not yet clearly understood. Could it be specialized knowledge, teaching style, experience or perhaps level of education? (Fan \& Ye, 2007; Opdenakker \& Van Damme 2006). More studies that focus on the teacher, with data obtained directly from the classroom and/or the students need to be conducted (Aitkin, Bennett, \& Hesketh, 1981; Hidalgo-Cabrillana \& Lopez-Mayan, 2018; Övez \& Uyangör, 2016). Therefore, as

Article History: Received 30 September $2018 \bullet$ Revised 14 November $2018 \bullet$ Accepted 23 December 2018

(C) 2019 by the authors; licensee Modestum Ltd., UK. Open Access terms of the Creative Commons Attribution 4.0 International License (http://creativecommons.org/licenses/by/4.0/) apply. The license permits unrestricted use, distribution, and reproduction in any medium, on the condition that users give exact credit to the original author(s) and the source, provide a link to the Creative Commons license, and indicate if they made any changes. 
it stands, one of the most basic needed skills for either a teacher or learner in the 21st century is technology. It is believed that ICT can be used as a powerful tool to support inclusion and that information on students' use of ICT can facilitate its integration (Bagon, Gacnik \& Starcic; 2018). Nonetheless, Salam, Zeng, Pathan, Latif and Shaheen (2018) stipulated that change is not easy; it requires overcoming the impediments that hinder the successful integration of ICT in public schools. Findings of their study revealed that intrinsic barriers are easy to surmount; once extrinsic barriers have been subdued successfully.

The first primary faculty characteristic of interest in this study is teaching style. Teaching styles are a combination of qualities, needs, beliefs, and behaviors that faculty display in the classroom and that are important in guiding and directing the way teachers teach (Grasha, 1996). Grasha is the predominant author associated with teaching styles, and he has published individual work as well as work with collaborators (Grasha, 1994, 1996; Grasha, \& Riechmann-Hruska, 1996). Teaching styles vary in degrees and are often blended together in practice; therefore it is difficult, and inappropriate from Grasha's view, to identify someone as having only one specific style type. The most frequently used tool appears to be the Teaching Style Survey developed by Grasha and Riechmann-Hruska (1996). This survey is a 40-item Likert scale that was developed for use by college teachers and is based on the work of Grasha over the course of his career. The Teaching Style Survey categorizes respondents into one of five teaching style types, which Grasha identified in his 1996 book, Teaching with Style. These types are:

Expert: This teacher is a transmitter of information who possesses knowledge that students need and strives to maintain his/her status as an expert among students by displaying detailed knowledge and by challenging students to enhance their competence. Experts are concerned with transmitting information and ensuring student preparation. The advantages of this style are that the teacher is seen to possess information, knowledge, and skills. A disadvantage of this style is that an overt display of knowledge can be intimidating to inexperienced students, and the underlying thought processes that produced the information may not be clear to learners.

Formal Authority: This approach focuses on content and can be very instructor-centered. The instructor defines the theories, principles, concepts or terms that the student needs to learn and organizes them into a sequenced set of goals or objectives. Evaluations are a necessary part of course planning as they allow the instructor to ascertain the amount of student learning that has taken place.

Demonstrator: This approach concentrates on the performance of an academic procedure. The instructor defines the steps an expert in the field would use to accomplish necessary tasks as well as defines the standards, which would indicate mastery in applying these procedures. The instructor then develops situations in which these steps can be performed and results observed. The instructor may be the one who demonstrates the procedures; students may be the ones practicing the procedures, or some combination of both.

Facilitator: Teachers who have a facilitator model teaching style tend to focus on activities. This teaching style emphasizes student-centered learning and there is much more responsibility placed on the students to take the initiative for meeting the demands of various learning tasks. Teachers typically design group activities, which necessitate active learning, student-to-student collaboration and problem solving.

Delegator: Teachers who practice a delegator teaching style tend to place control and responsibility for learning on individuals or groups of students. This teacher will often give students a choice in designing and implementing their own complex learning projects and will act in a consultative role.

Grasha (1996) proposes an integrated teaching model that suggests that every teacher possesses each of the five styles to a varying range of degrees and often in "clusters or blends" of teaching styles. According to Grasha, the order of each style in the cluster reflects the perceived importance of that style in the blend and this indicates that all styles possess different advantages and disadvantages that if taken to an extreme, have the potential to cause anxiety for the learner and actually inhibit learning.

González, Conde, Díaz, García and Ricoy (2018) postulated that instructors' teaching styles in higher education are an issue of major importance because these interactions affect students' self-perceptions, involvement, and achievement. As practical implications, their study clearly revealed the need for different interventions to enhance adequate instructors' teaching styles and to foster among novice pre-service teachers the acquisition of professional competences, initial self-efficacy, and a good level of commitment to their profession. 
According to Li, Zheng and Yang (2017), in their recent study, they conclude that the prevalence of online e-teaching, particularly the assistance of MOOCs, has a flipped classroom develop into the new trend of digital learning. With changing information technology, multimedia digital teaching is constantly impacting original teaching styles; multiple knowledge are presented through texts, pictures, and clear audio with sound and light effects; and, even learning environments and learning materials are simulated to induce students' learning interests and enhance the teaching effect (Wu \& Tai, 2016).

Van Vraak, Tondeur and Valcke (2004) have established a strong relationship between ICT related attitudes and use in the classroom for educational purposes. Many studies in the field of ICT in education have shown that attitudes towards ICTs influence teachers' acceptance of the usefulness of ICTs in the lessons, and also influence whether teachers integrate ICTs into their classrooms or not (Clark, 2001; Huang \& Liaw, 2005). It is believed in the mathematics education community that appropriate integration of ICT will impact every aspect of mathematics education: what kind of mathematics is to be presented and how mathematics is taught and learned (Leung, 2013). Effective use of ICT in mathematics education could lead to a more learnercentered teaching practice, since the integration of ICT fundamentally changes the teacher-student interaction and the ways mathematics content is being presented to students (Ertmer, 2005; Gillen, Staarman, Littleton, Mercer, \& Twiner, 2007; Pierce \& Ball, 2009). These changes have been commonly believed to have positive effect on mathematics teaching and learning. For example, the use of ICT can enrich students' mathematics learning experience improve students' interests in learning mathematics, and change their attitudes towards mathematics (Goos \& Bennson, 2008; Jimoyiannisa \& Komis, 2007; Pierce \& Ball, 2009). Although ICT is believed to have positive benefits on mathematics education, in reality, sometimes teachers do not use ICT at all or use it in a very traditional way, like using ICT to sustain direct teaching (Ertmer, 2005; Goos \& Bennson, 2008). Teachers' attitudes towards and beliefs about the use of ICT have been argued as a critical barrier for teachers to adopt and make effective use of ICT in practice (Ertmer, OttenbreitLeftwich, Sadik, Sendurur, \& Sendurur, 2012; Pierce \& Ball, 2009; Prestridge, 2012). More importantly, the effective integration of ICT can make mathematics (e.g., abstract concepts) more accessible to students and further facilitate students' understanding of mathematics concepts, develop students' problem solving skills, improve students' higher levels of mathematical thinking, and even generally improve students' mathematics achievement (Goos \& Bennson 2008; Li \& Ma, 2010).

Researchers have found that teachers' attitudes toward ICT were a much greater indicator of their intention to the use of technology than their beliefs, like self-efficacy beliefs (Prestridge, 2012; Sangcap, 2010). Generally more favorable attitudes towards ICT will encourage higher classroom ICT integration while negative attitudes discourage the use of it (Jimoyiannis \& Komis, 2007; Sangcap, 2010). In mathematics education, it was found that it is only when teachers believe that the use of ICT will enhance students' mathematics learning or increase students' motivation, enjoyment and confidence compared with other approaches that they will consider to use technology (Hennessy, Ruthven, \& Brindley, 2005; Pierce \& Ball, 2009). If teachers believe that in order to demonstrate understanding of mathematics, a student must be able to solve problems without the assistance of ICT, or even believe that the use of ICT will hinder the development of students' ability, such as the ability of calculation, they will not integrate ICT in mathematics education, or use it in a very traditional knowledge transmission way (Goos \& Bennson, 2008; Pierce \& Ball, 2009).

In relation to gender, researchers studying the differences between ICT use of male and female students have focused on the impact of gender on attitudes related to ICT use (Dix, 2005; Kubiatko \& Halakova, 2011; Kuhlemeier \& Hemker, 2007) role of gender in the ICT-maths performance relationship (Meggiolaro, 2018), Technological Pedagogical Content Knowledge (TPACK) and ICT use based on gender (Saltan \& Arslan, 2017), resistance to digital means of communication (Macià \& Garreta, 2018), frequency of ICT use (Uslu, 2018) and types of activities using ICT by gender and working experience of lecturers who were working at higher education institution in Malaysia (Hussain, Din, Khidzir, Daud, \& Ahmad, 2018).

In teacher education in Spain, little has been done so far in research about pre-service Primary mathematics teachers' teaching styles and their attitudes towards the use of technology in mathematics classrooms. Hence, the main objective of this study is to investigate Spanish pre-service Primary teachers' teaching styles and their attitudes towards the use of technology in the mathematics classrooms and the relationships between both features. The collected data will be analyzed through the lens of the Modified Acceptance Model (TAM) by Davis, Bagozzi and Warshaw's (1989), which this study has adopted as a theoretical framework (see Figure 1). The TAM approach focuses on how the external domain, such as professional development (PD), and the accessibility of technology influence participants' beliefs about the usefulness, and ease of use of technology, which in turn impacts their actual use in teaching. 


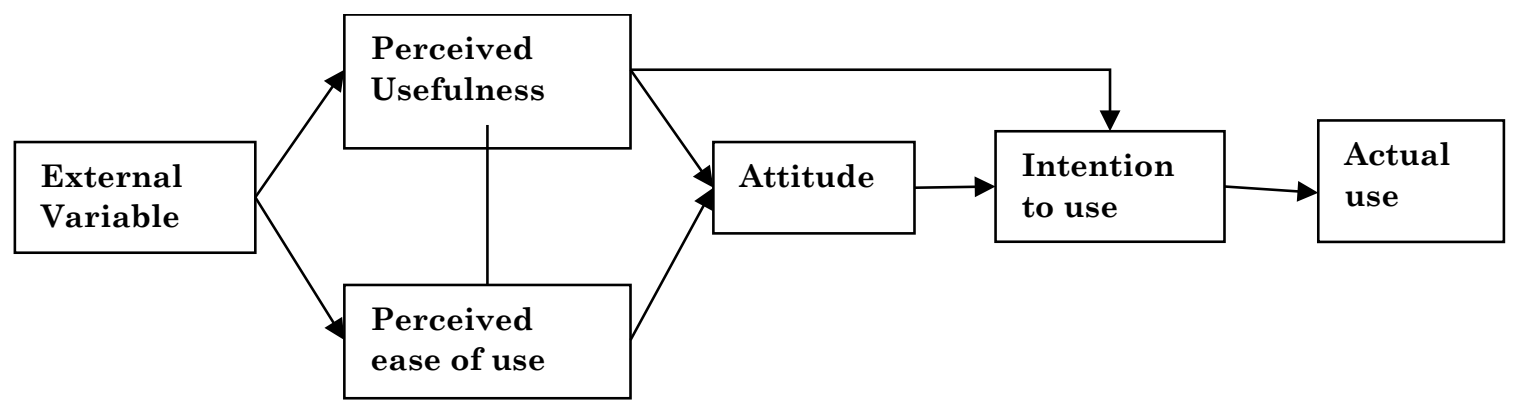

Figure 1. The Technology Acceptance Model (Davis, 1986; Davis et al. 1989)

Perceived usefulness and perceived ease of use are two primary determinants of technology acceptance. Attitude towards technology use is jointly determined by perceived usefulness and perceived ease of use. The latter influences the behavioral intention to use the technology that - in turn - determines the actual adoption and use of technology (Venkatesh \& Davis, 2000). External variables such as training on intention to use are mediated by the former internal processes (Venkatesh \& Davis, 2000).

This model has been widely used in empirical studies on user technology acceptance and integration as a theoretical basis. For example, in studies done by (Adedoja, Adelore, Egbokhare, \& Oluleye, 2013; Davis, 1986; Davis et. al., 1989; Kumar, Rose, \& D'Silva, 2008; Mathieson, 1991). TAM has become the most commonly and popular used theoretical framework for technology user studies and it is also found to be imperative in explaining instructional use of educational support systems and examining the external factors that influence the usage of these systems. Taking such background into account, the research framework adopted in this study uses the constructs of the TAM. Moreover, according to authors like Masrom (2007), technology acceptance is an "individual's psychological state with regard to his or her voluntary or intended use of a particular technology" and, on the other hand, it can be easily seen that in TAM the main dependent factor is the behavioral intention to use and actual system usage while the main independent factors are attitude, perceived usefulness and perceived ease of use.

After the results have been established, analyzed and discussed thoroughly in this work, we will be able to determine if there is a significant difference in Spanish mathematics student teachers' attitudes towards use of technology based on gender and year of study and whether there is any relationship between pre-service primary teachers' teaching styles and their attitude towards the use of technology in mathematics classrooms or not.

\section{METHODOLOGY}

This study used a quantitative research approach underpinned by the positivism paradigm. The study employed the survey model. Therefore, a quantitative descriptive survey design was adopted in this study because learners' scores were used to describe the phenomenon being investigated (Okitowamba, Julie, \& Mbekwa, 2018).

In order to collect data from Spanish student teachers, the survey method was employed. To ameliorate these partiality and biasness, the researcher's goal must be to strive for absolute truth and accurate understanding or meaning. In quantitative research, knowledge is obtained through deductive testing of hypothesis to examine the relationship between dependent and independent variables. In particular, crosssectional survey method of data collection has been adopted. This involves collecting information at just one point in time from a sample that has been drawn from a predetermined population by administering a questionnaire or ability test to individuals to find out specific characteristics of the group (Fraenkel \& Wallem, 2000).

\section{Participants}

One hundred sixty three (163) pre-service primary mathematics teachers participated in this study. These were students at the University of Valladoid (Spain) who have to complete four years in order to receive a bachelor's degree. Convenience sampling method was used to determine the sample for this study. Of the 163 participants, 45 were males and 118 were females. Fifty-four were first year students, 65 were second year and 44 were forth year. Third year students were not included in the sampling as they all were out of class at the time the study was being conducted due to their teaching practice period. Participation was voluntary and 
Table 1. Analysis of student teachers' attitudes towards use of technology based on gender

\begin{tabular}{lcccc}
\hline \multirow{2}{*}{ Gender } & \multirow{2}{*}{ Mean } & \multirow{2}{*}{ Std. Error } & \multicolumn{2}{c}{ 95\% Confidence Interval } \\
\cline { 4 - 5 } & & & Lower Bound & Upper Bound \\
\hline Male & 82.127 & 2.327 & 77.530 & 86.723 \\
\hline Female & 91.747 & 1.404 & 88.973 & 94.522 \\
\hline
\end{tabular}

Table 2. Analysis of student teachers' attitudes towards use of technology based on year of study

\begin{tabular}{lcccc}
\hline \multirow{2}{*}{ Year } & \multirow{2}{*}{ Mean } & \multirow{2}{*}{ Std. Error } & \multicolumn{2}{c}{ 95\% Confidence Interval } \\
\cline { 4 - 5 } & & 2.406 & Lower Bound & Upper Bound \\
\hline First year & 87.910 & 2.089 & 83.157 & 92.663 \\
\hline Second year & 87.255 & 2.543 & 83.128 & 91.381 \\
\hline Fourth year & 87.646 & 80.622 & 90.670 \\
\hline
\end{tabular}

the response rate was around $95 \%$. Written consent was obtained from each of the participants in the survey and in order to maintain anonymity, the names of participants were not used and not recorded in the data files. Participants were informed that there were no known risk(s) associated with participating in this study, and of their right to withdraw from the study at will. Participants were also guaranteed that no identifiable references would be made in the final paper.

\section{Data Collection Tools}

In order to evaluate the student teachers' teaching styles, Grasha-Riechmann's Teaching Styles Questionnaire was used. The questionnaire includes 40 items that all are related to five different types of teaching and learning and it is used to measure teacher's or lecturer's teaching style preferences. Participants rated their agreement with each item on a 5-point Likert scale (5 = Strongly Agree, $4=$ Moderately Agree, $3=$ Undecided, 2 = Moderately Disagree, $1=$ Strongly Disagree). The questionnaire was constructed to measure the independent variable, which is teachers' teaching style. Secondly, in order to measure the dependent variable "attitude towards ICT use" the instrument developed by Sánchez, Mena, González and GuanLin (2012) to measure attitudes to technological resources in the mathematics classroom has been used. This instrument includes 25 positively worded statements relating to successful integrating technology into teaching practices and participants must rate each item on a 5 -point Likert scale $(5=$ completely agree, $4=$ moderately agree, $3=$ neither agree nor disagree, $2=$ moderately disagree, $1=$ strongly disagree).

\section{Data Analysis}

To analyze the data, "IBM" SPSS Statistics version 23 was used to run the analysis of variances (ANOVA) to check the mean differences in Spanish mathematics student teachers' attitudes towards the use of technology based on gender and year of study and step-wise multiple linear regression analysis was used to determine the relationship between pre-service primary teachers' teaching styles and their attitude towards the use of technology in mathematics classrooms.

\section{RESULTS}

In this section, results of the ANOVA and step-wise multiple regression analysis are presented and interpreted. Thus, results in Table 1 show that there is a statistically significant difference based on gender in the attitudes towards the use of technology scores of student teachers for males and females. These results suggest that at the confidence interval of $95 \%$, gender have an effect on student teachers' attitudes towards the use of technology and male student teachers $(\mathrm{M}=82.127$, Std error $=2.327)$ have lower attitude values than females $(M=91.747$, Std error = 1.404). Thus, the differences in the pre-service teachers' attitudes towards the use of technology could be attributed by gender.

It can be seen from the results in Table 2 that at the $95 \%$ confidence interval, [1st year M=87.910, 2nd year $\mathrm{M}=87.255$ and 4 th year $\mathrm{M}=87.646]$, there is no significant difference based on year of study in the mean scores of student teachers for males and females. These results suggest that year of study does not have an effect on student teachers' attitudes towards the use of technology.

In this study, five teaching styles are measured by the student teachers' responses to the 40 items in the questionnaire. Five dimensions of teachers' teaching styles are: the dimensions of expert, the dimensions of 
Table 3. Domain item distribution of student teachers' teaching style

\begin{tabular}{llcc}
\hline Type of style & Mean & Std. Deviation & $\mathbf{N}$ \\
\hline Expert & 3.6465 & .42952 & 163 \\
\hline Formal & 3.3355 & .43584 & 163 \\
\hline Personal & 3.6135 & .46030 & 163 \\
\hline Facilitator & 4.0455 & .53676 & 163 \\
\hline Delegator & 3.5909 & .50609 & 163 \\
\hline
\end{tabular}

Table 4. Analysis of the relationship between pre-service primary teachers' teaching styles and their attitude towards the use of technology

\begin{tabular}{cccccc}
\hline Model & $\mathbf{R}$ & R Square & Adjusted R Square & Std. Error of the Estimate & Durbin-Watson \\
\hline 1 & $.305 \mathrm{a}$ & .093 & .087 & 14.99886 & \\
\hline 2 & $.372 \mathrm{~b}$ & .139 & .127 & 14.66727 & \\
\hline 3 & $.413 \mathrm{c}$ & .171 & .154 & 14.43946 & 1.757 \\
\hline 4 & $.451 \mathrm{~d}$ & .204 & .182 & 14.19944 & \\
\hline
\end{tabular}

a. Predictors: (Constant), Intensity_Facilitator

b. Predictors: (Constant), Intensity_Facilitator, Gender

c. Predictors: (Constant), Intensity_Facilitator, Gender, Age

d. Predictors:(Constant),Intensity_Facilitator, Gender, Age, intensity_Expert

e. Dependent Variable: ATICT_Use

formal authority, the dimensions of personal model, the dimensions of facilitator and the dimensions of delegator.

According to Table 3, the dimensions of facilitator model has the highest mean score of 4.0455 , followed by expert teaching style dimensions is ranked second with the mean of 3.6465. Personal teaching style (3.6135) is higher than the mean of formal authority dimensions (3.3355), and the mean of delegator dimensions (3.5909). Formal authority dimensions have the lowest mean score (3.3355). The findings show that there are many student teachers at the University of Valladolid using facilitator model teaching style and expert teaching style. The student teachers are also using the formal authority teaching approach, personal model and delegator style in class. The authors of the current paper agree with the findings of Arias, Galdos and Ceballos (2018) in their paper "teaching styles and self-regulation of learning in students of education at St. Pablo Catholic University", their results indicated that the most frequent teaching styles were the Expert type, Facilitator and Delegator. There were also, low but significant correlations between self-regulated learning and the following teaching styles: Formal authority, Personal model and Delegator.

Results from Table 4 show the variability in the student teachers' attitudes towards use of technology as explained by the four predictor variables. The adjusted $\mathrm{R}$ square column indicates that about $9 \%$ of total variability in the dependent variable that is, the pre-service teachers' attitudes towards the use of ICT is explained by the facilitator teaching style, $13 \%$ of total variability is explained by two predictor independent variables (IVs) gender and the facilitator teaching style, 15\% is explained by three IVs facilitator, gender and age of the students. Lastly, all the four (4) model predictors explain about $18 \%$ of the total variability in the DV. Since the discrepancy between the R-square and the Adjusted R-square was very small, there was no redundancy in the inclusion of the IVs in the model. All the four IVs had the ability to predict the linear regression model. Therefore, pre-service teachers' attitudes towards the use of ICT could be significantly explained by four predictors; two teaching styles, gender and age. These showed a strong ability of prediction of incorporating ICT in the teaching of mathematics. The model below gives the relationship:

$$
\mathrm{y}=0.305 \mathrm{a}+0.372 \mathrm{~b}+0.413 \mathrm{c}+0.451 \mathrm{~d}
$$

Finally Table 5 shows the ANOVA testing the statistical significance of the model at each step. The most important model was the last one, which included all predictors. Further analysis of the table showed that the F-values associated with the models were decreasing as you go down at each step of the model as you increase the number of independent variables in the model. That is, $\mathrm{F}=15.214>\mathrm{F}=11.839>\mathrm{F}=10.035>\mathrm{F}=9.277$. The pre-service teachers' attitudes towards the use of ICT are significantly explained by four predictors of which the teaching styles (the facilitator teaching style) contribute the most and shows a strong relationship. 
Table 5. The ANOVA table in regression (Further analysis of the regression model)

\begin{tabular}{|c|c|c|c|c|c|c|}
\hline & Model & Sum of Squares & Df & Mean Square & $\mathbf{F}$ & Sig. \\
\hline \multirow{3}{*}{1} & Regression & 3422.740 & 1 & 3422.740 & 15.214 & $.000^{\mathrm{b}}$ \\
\hline & Residual & 33294.960 & 148 & 224.966 & & \\
\hline & Total & 36717.700 & 149 & & & \\
\hline \multirow{3}{*}{2} & Regression & 5093.746 & 2 & 2546.873 & 11.839 & $.000^{\mathrm{c}}$ \\
\hline & Residual & 31623.954 & 147 & 215.129 & & \\
\hline & Total & 36717.700 & 149 & & & \\
\hline \multirow{3}{*}{3} & Regression & 6276.988 & 3 & 2092.329 & 10.035 & $.000^{\mathrm{d}}$ \\
\hline & Residual & 30440.712 & 146 & 208.498 & & \\
\hline & Total & 36717.700 & 149 & & & \\
\hline \multirow{3}{*}{4} & Regression & 7482.205 & 4 & 1870.551 & 9.277 & $.000^{\mathrm{e}}$ \\
\hline & Residual & 29235.495 & 145 & 201.624 & & \\
\hline & Total & 36717.700 & 149 & & & \\
\hline
\end{tabular}

a. Dependent Variable: ATICT_Use

b. Predictors: (Constant), Intensity_Facilitator

c. Predictors: (Constant), Intensity_Facilitator, Gender

d. Predictors: (Constant), Intensity_Facilitator, Gender, Age

e. Predictors: (Constant), Intensity_Facilitator, Gender, Age, Intensity_Expert

\section{DISCUSSION AND CONCLUSIONS}

The results presented in the previous section indicate that pre-service teachers' year of study has no significant impact on the integration of ICT in the teaching and learning of mathematics while teaching styles and gender do have. In relation to the matter of gender results seem to be somehow contradictory with previous studies such as those by Meggiolaro (2018) or Bagon, Gacnik and Starcic (2018), not in the sense of gender appearing to be a variable that matters when looking at attitudes towards the use of ICT in mathematics classrooms but with respect to the direction of such differences. Thus, on the one hand, the results obtained by Meggiolaro (2018) showed that association between ICT and maths performance was weaker for girls and those by Bagon, Gacnik and Starcic (2018) revealed that boys use computers more frequently, and have a stronger belief that computer use improves learning success. However, on the other hand, our current study indicates that at the confidence interval of 95\% attitude towards the use ICT in mathematics classroom is stronger or more positive in female pre-service teachers than it is in males. In order to understand why this might be happening it must be taken into account that the studies performed by Meggiolaro and Bagon and his colleagues, among many others, were considering attitudes towards ICT from the point of view of participants focusing exclusively or mainly on learning while our study captures answers from pre-service teachers being thus a sample of participants where learning and teaching focus must coexist. This mean that our participants were answering questions as prospective teachers and hence affected by the combination of their own learning and developing teaching styles. Moreover, they were also acquiring pedagogical content knowledge in their studies, which include topics related to the effective use of ICT in education. Both factors might help in the explanation of the differences found between our research and previous studies like the two mentioned above although new data would be needed in order to confirm such differences and, above all, to understand why male and female students interchange their attitudes in such a way.

On the contrary, the year of study had no significant effect on the attitudes towards the use of technology. Therefore, it makes no difference whether the students are in first year, second year or fourth year. According to table 4 , the results revealed an acceptable fit between the model $(y=0.305 a+0.372 b+0.413 c+0.451 d)$ and the data. Therefore, it is evident that there was a positive linear relationship between pre-service primary teachers' teaching styles and their attitude towards the use of technology in mathematics classrooms.

The authors of the current paper agree with the findings of Uslu (2018), who also came up with an acceptable fit between the model and the data, he further reported that Technological Pedagogical Content Knowledge, attitude towards technology use in education, gender, frequency of computer use, seniority, duration of computer use, technical support, and individual innovativeness have direct or indirect effects on technology integration. Consistent with the findings of Ruiz-Jaramillo and Vargas-Yáñez (2018) and Gaitanaru (2014), Spanish Student teachers at the University of Valladolid showed positive attitudes towards the use of ICT-based methodology and teaching styles described above, this leads to students being more involved and motivated by the subject, favoring that pre-service teachers' attitudes towards use of technology 
is significantly predicted by age, gender and different styles of teaching mathematics in the digital era. From the research findings in Tables 1 and 4, it is very clear that mathematics teachers at the University of Valladolid do have positive attitudes towards the integration of ICTs in the teaching and learning of mathematics. This is consistent with the findings of Brown (2017). Nevertheless, this is contrary to the findings on Czech and Polish students done by Tomczyk et al. (2017), which revealed different attitudes toward applying digital solutions to the didactic process. Factors such as low evaluation of one's own competences or lack of evaluation in this area, lack of creative approach to the use of new media, lack of education in the area of new applications, lack of skills necessary to handle basic digital tools (e.g. interactive board, e-learning platforms) negatively affect, in most cases, the attitude toward the active use of ICT tools in future didactic work.

In light of the findings reported above, we thus, wish to recommend that policy decision on the integration of ICT in schools should be taken on the basis of research evidence rather than supposition and political expediency; a qualitative study may be carried out on this same topic to better explore and understand preservice teachers' teaching styles and their attitudes towards the use of technology in mathematics classrooms; studies focusing on ICT based teaching styles in mathematics may be carried out in other Universities offering teacher training programs, findings of this nature, present opportunities to teacher trainers and researchers at the University of Valladolid to come up with programs aimed at developing both trainee and in-service teachers' knowledge of effective integration of technology in mathematics instruction.

The findings from this study are useful in addressing each of the research questions. The objectives of the study have been met. The data provide valuable information that can add to what is known. The research results correspond with the conclusions of other researchers, which indicate certain regularity. This study has revealed the preferred teaching styles and the attitudes towards the use technology of pre-service teachers at the University of Valladolid. It has been shown that there is no significant development in pre-service teachers' attitudes towards the use of technology according to year of study.

This study aimed at proposing a model to improve pre-service teachers' teaching styles through technology integration. To this end, data on variables that affect technology integration were collected from 163 student teachers at the University of Valladolid and analyzed by using ANOVA and step-wise multiple regression analysis. The results revealed an acceptable fit between the model and the data. The variables of interest were: Student teachers' attitude towards technology use in education, teaching styles, gender and year of study. The developed multiple linear regression model $(y=0.305 a+0.372 b+0.413 c+0.451 d)$ could be considered original because it includes the variables of individual creativeness. Based on the developed strong relationship between pre-service primary teachers' teaching styles and their attitude towards the use of technology in mathematics classrooms, some suggestions were presented to support mathematics classroom instructions.

\section{ACKNOWLEDGEMENT AND FUNDING}

Acknowledgement is due to the Department of Experimental Sciences, Social Sciences and Mathematics and the Faculty of Education and Social Work of the University of Valladolid for providing an enabling Professional Learning Environment where intellectual discourses took place and provided a platform to critique one another's manuscripts. This article benefitted immensely from those interactions.

This research is supported by the European Commission within the framework of "Erasmus Mundus Programme, Action 2- SRAND 1, Lot 18, ACP Countries". Any opinions, findings and conclusions or recommendations expressed in this material are those of the authors and do not necessarily reflect the views of the DREAM ACP Mobility Project funders nor the University of Porto, as coordinating institution of the DREAM Project.

\section{Disclosure statement}

No potential conflict of interest was reported by the authors.

\section{Notes on contributors}

José M. Marbán - University of Valladolid, Spain.

Eddie M. Mulenga - The Copperbelt University, Zambia. 


\section{REFERENCES}

Adedoja, G., Adelore, O., Egbokhare, F., \& Oluleye, A. (2013). Learners' acceptance of the use of mobile phones to deliver tutorials in a distance learning context: a case study at the University of Ibadan. The African Journal of Information Systems, 5(3), 80-93.

Aitkin, M., Bennett, S. N., \& Hesketh, J. (1981). Teaching styles and pupil progress: a re-analysis. British Journal of Educational Psychology, 51(2), 170-186. https://doi.org/10.1111/j.2044-8279.1981.tb02471.x

Arias, W.L., Galdos, D., \& Ceballos, K.D. (2018). Teaching styles and self-regulation of learning in students of education at St. Pablo Catholic University. Journal of Learning Styles, 11(21), 95-123

Bagon, S., Gacnik, M., \& Starcic, A. I. (2018). Information Communication Technology Use among Students in Inclusive Classrooms. International Journal of Emerging Technologies in Learning, 13(6), 56-72. https://doi.org/10.3991/ijet.v13i06.8051

Brown, J. P. (2017). Teachers' perspectives of changes in their practice during a technology in mathematics education research project. Teaching and Teacher Education, 64, 52-65. https://doi.org/10.1016/j.tate.2017.01.022

Clark, K. D. (2001). Urban middle school teachers' use of instructional technology. Journal of Research on Computing in Education, 33(2), 178-195. https://doi.org/10.1080/08886504.2000.10782308

Davis, F. D. (1986). A technology acceptance model for empirically testing new end-user information systems: theory and results (Doctoral dissertation). Sloan School of Management, MIT, 1986

Davis, F. D., Bagozzi, R. P., \& Warshaw, P. R. (1989). User acceptance of computer technology: A comparison of two theoretical models. Management Science, 35, 982-1003. https://doi.org/10.1287/mnsc.35.8.982

Dix, K. (2005). Are learning technologies making a difference? A longitudinal perspective of attitudes. International Educational Journal, 5, 15-28.

Ertmer, P. (2005). Teacher Pedagogical beliefs: The final frontier in our quest for technology integration? Educational Technology Research and Development, 53(4), 25-39. https://doi.org/10.1007/BF02504683

Ertmer, P. A., Ottenbreit-Leftwich, A. T., Sadik, O., Sendurur, E., \& Sendurur, P. (2012). Teacher beliefs and technology integration practices: A critical relationship. Computers \& Education, 59(2), 423-435. https://doi.org/10.1016/j.compedu.2012.02.001

Fan, W., \& Ye, S. (2007). Teaching styles among Shanghai teachers in primary and secondary schools. Educational Psychology, 27(2), 255-272. https://doi.org/10.1080/01443410601066750

Fraenkel, R. J., \& Wallen, E. N. (2000). How to design and evaluate research in education (4th ed.). San Francisco: McGraw-Hill.

Gaitanaru, A. (2014). Advantages and difficulties of implementation of new information technologies in education: let's build the future through learning innovation. En Ion Roceanu (Ed.): Proceedings of the $10^{\text {th }}$ International Conference "eLearning and Software for Education", Vol. 3 (pp. 205-209). Bucharest: Editura Universitatii Nationale de Aparare "Carol I". https://doi.org/10.12753/2066-026X-14-172

Gillen, J., Staarman, J. K., Littleton, K., Mercer, N., \& Twiner 2, A. (2007). A 'learning revolution'? Investigating pedagogic practice around interactive whiteboards in British primary classrooms. Learning, Media and Technology, 32(3), 243-256. https://doi.org/10.1080/17439880701511099

González, A., Conde, Á., Díaz, P., García, M. \& Ricoy, C. (2018). Instructors' teaching styles: relation with competences, self-efficacy, and commitment in pre-service teachers. Higher Education, 75(2), 625-642. https://doi.org/10.1007/s10734-017-0160-y

Goos, M., \& Bennson, A. (2008). Surveying the technology landscape: Teachers' use of technology in secondary mathematics classrooms. Mathematics Education Research Journal, 20(3), 102-130. https://doi.org/10.1007/BF03217532

Grasha, A. F. (1994). A matter of style: The teacher as a expert, formal authority, personal model, facilitator and delegator. College Teaching, 42(4), 142-49. https://doi.org/10.1080/87567555.1994.9926845

Grasha, A. F. (1996). Teaching with style: A practical guide to enhance learning by understanding learning and teaching style. Pittsburgh, PA: Alliance Publishers

Grasha, A.F., \& Reichmann-Hruska, S. (1996). Teaching style survey. Cincinnati, OH: University of Cincinnati. 
Hennessy, S., Ruthven, K., \& Brindley, S. (2005). Teacher perspectives on integrating ICT into subject teaching commitment, constraints, caution, and change. Journal of Curriculum Studies, 37(2), 155-192. https://doi.org/10.1080/0022027032000276961

Hidalgo-Cabrillana, A., \& Lopez-Mayan, C. (2018). Teaching styles and achievement: student and teacher perspectives. Economics of Education Review. https://doi.org/10.1016/j.econedurev.2018.10.009

Huang, H. M., \& Liaw, S. S. (2005). Exploring users' attitudes and intentions toward the Web as a survey tool. Computers in Human Behavior, 21(5), 729-743. https://doi.org/10.1016/j.chb.2004.02.020

Hussain, H. S., Din, R., Khidzir, N. Z., Daud, K. A. M., \& Ahmad (2018). Risk and Threat via Online Social Network among Academia at Higher Education. Journal of Physics: Conference Series (Vol. 1018, No. 1, p.012008). IOP Publishing. https://doi.org/10.1088/1742-6596/1018/1/012008

Jimoyiannis, A., \& Komis, V. (2007). Examining teachers' beliefs about ICT in education: Implications of a teacher preparation programme. Teacher Development, 11(2), 149-173. https://doi.org/10.1080/13664530701414779

Kubiatko, M., \& Halakova, Z. (2011). Slovak high school students' attitudes to ICT using in biology lesson. Computers in Human Behavior 25(3), 743-748. https://doi.org/10.1016/j.chb.2009.02.002

Kuhlemeier, H., \& Hemker, B. (2007). The impact of computer use at home on students' Internet skills. Computer \& Education, 49, 460-480. https://doi.org/10.1016/j.compedu.2005.10.004

Kumar, N., Rose, R.C., \& D’Silva, J. L. (2008). Teachers' readiness to use technology in the classroom: an empirical study. European Journal of Scientific Research 21(4), 603-616. Retrieved on July 30, 2017 from http://www.eurojournals.com/ejsr.htm

Leung, F. K. S. (2013). Introduction to section: Technology in Mathematics Curriculum. In M. A. Clements, A. J. Bishop, C. Keitel, J. Kilpatrick, \& F. K. S. Leung (Eds.): Third international handbook of mathematics education (pp. 517-524). New York: Springer.

Li, Q., \& Ma, X. (2010). A meta-analysis of the effects of computer technology on school students' mathematics learning. Educational Psychology Review, 22(3), 215-243. https://doi.org/10.1007/s10648-010-9125-8

Li, Y. B., Zheng, W. Z., \& Yang, F. (2017). Cooperation Learning of Flip teaching style on the MBA Mathematics Education Efficiency. Eurasia Journal of Mathematics Science and Technology Education 13(10), 6963-6972. https://doi.org/10.12973/ejmste/76878

Macià, M., \& Garreta, J. (2018). Accessibility and digital literacy: barriers to the integration of ICT in family / school communication. Educational Research Journal, 36(1), 239-257. https://doi.org/10.6018/rie.36.1. 290111

Masrom, M. (2007). Technology Acceptance Model and E-learning. [Online]. Retrieved on 26 Aug 2018 from http://eprints.utm.my/5482/1/MaslinMasrom2006_techn.pdf

Mathieson, K. (1991). Predicting user intentions: comparing the Technology Acceptance Model with the Theory of Planned Behavior. Information Systems Research, 2(3), 173-191. https://doi.org/10.1287/isre.2.3.173

Meggiolaro, S. (2018). Information and communication technologies use, gender and mathematics achievement: evidence from Italy. Social Psychology of Education, 21(2), 497-516. https://doi.org/10.1007/s11218-017-9425-7

Okitowamba, O., Julie, C., \& Mbekwa, M. (2018). The effects of examination-driven teaching on mathematics achievement in Grade 10 school-based high-stakes examinations. Pythagoras, 39(1), a377. https://doi.org/10.4102/pythagoras.v39i1.377

Opdenakker, M. C., \& Van Damme, J. (2006). Teacher characteristics and teaching styles as effectiveness enhancing factors of classroom practice. Teaching and teacher education, 22(1), 1-21. https://doi.org/10.1016/j.tate.2005.07.008

Övez, F. T. D., \& Uyangör, S. M. (2016). The Effect of the Match between the Learning and Teaching Styles of Secondary School Mathematics Teachers on Students' Achievement. Journal of Education and Practice, $7(29), 125-132$.

Pierce, R., \& Ball, L. (2009). Perceptions that May Affect Teachers' Intention to Use Technology in Secondary Mathematics Classes. Educational Studies in Mathematics, 71(3), 299-317. https://doi.org/10.1007/s10649-008-9177-6

Prestridge S. (2012). The beliefs behind the teacher that influences their ICT practices. Computers \& Education, 58(1), 449 458. https://doi.org/10.1016/j.compedu.2011.08.028 
Ruiz-Jaramillo, J., \& Vargas-Yáñez, A. (2018). La enseñanza de las estructuras en el Grado de Arquitectura. Metodología e innovación docente a través de las TIC | Teaching structures on Architecture degrees. ICT-based methodology and teaching innovation. Revista Española de Pedagogía, 76(270), 353-372. https://doi.org/10.22550/REP76-2-2018-08

Salam, S., Zeng, J. Q., Pathan, Z. H., Latif, Z., \& Shaheen, A. (2018). Impediments to the Integration of ICT in Public Schools of Contemporary Societies: A Review of Literature. Journal of Information Processing Systems, 14(1), 252-269. https://doi.org/10.3745/JIPS.04.0062

Saltan, F., \& Arslan, K. (2017). A comparison of in-service and pre-service teachers' technological pedagogical content knowledge self-confidence. Cogent Education 4, p. 1311501. https://doi.org/10.1080/2331186X. 2017.1311501

Sánchez, A. B., Mena, J. J., González, M., \& GuanLin, H. (2012). In service teachers' attitudes towards the use of ICT in the classroom. Procedia-Social and Behavioral Sciences, 46, 1358-1364. https://doi.org/10.1016/j.sbspro.2012.05.302

Sangcap, P. G. A. (2010). Mathematics-related Beliefs of Filipino College Students: Factors Affecting Mathematics and Problem Solving Performance. Procedia - Social and Behavioral Sciences, 8, 465-475. https://doi.org/10.1016/j.sbspro.2010.12.064

Tomczyk, Ł., Szotkowski, R., Fabiś, A., Wasiński, A., Chudý, Š., \& Neumeister, P. (2017). Selected aspects of conditions in the use of new media as an important part of the training of teachers in the Czech Republic and Poland - differences, risks and threats. Education and Information Technologies 22(3), 747-767. https://doi.org/10.1007/s10639-015-9455-8

Uslu, O. (2018). Factors Associated with Technology Integration to Improve Instructional Abilities: A Path Model. Australian Journal of Teacher Education, 43(4), 31-50. https://doi.org/10.14221/ajte.2018v43n4.3

Van Braak, J., Tondeur, J., \& Valcke, M. (2004). Explaining different types of computer use among primary school teachers. European Journal of Psychology of Education, 19, 407-422. https://doi.org/10.1007/BF03173218

Venkatesh, V., \& Davis, F. D. (2000). A theoretical extension of the technology acceptance model: Four longitudinal field studies. Management Science, 46(2), $186-204$. https://doi.org/10.1287/mnsc.46.2.186.11926

Wu, T. J., \& Tai, Y. N. (2016). Effects of multimedia information technology integrated multi-sensory instruction on students' learning motivation and outcome. EURASIA Journal of Mathematics, Science and Technology Education, 12(4), 1065-1074. 